\title{
"THE FIRST STEAM ENGINE IN AMERICA"
}

\author{
BY RICHARD P. MC CORMICK
}

WhILE preparing a study of New Jersey politics after the Revolution, the author of this article came upon the letter by Josiah Hornblower which is here printed. Mr. McCormick, a graduate of Rutgers, studied last year at the University of Pennsylvania on a grant from the Rutgers Research Council. He is on the staff of the Department of History.

I

N September, I 753, the little snow ${ }^{1}$ Irene arrived in New York after a passage of twelve weeks from London with a cargo that included the first Newcomen or Cornish "fire engine" to reach America. Accompanied by a young British engineer, Josiah Hornblower, the primitive steam engine was destined for the famous copper mine owned by Colonel John Schuyler at Second River (now North Arlington) in New Jersey, where it was to be employed in pumping the deep shafts free of water. By the early part of I 755 the machine had been transported to Newark, assembled, and placed in operation, and for the next two decades it gave intermittent service. The history of this precursor of the age of steam has been recorded by numerous writers and need not be retold in detail here. ${ }^{2}$ But one important incident in the story, long clouded in doubt and befogged by conflicting sources, is in need of clarification.

Although it has been known that on one or more occasions the engine was put out of commission by fires that destroyed the building in which it was housed, it has never been definitely established when these disasters occurred. Benjamin H. Latrobe, the distinguished architect and engineer, stated that there were two fires, one in $176 \mathrm{I}$, and a second-started by a disgruntled workman-in $1765 .^{3} \mathrm{~A}$ later authority, Thomas F. Gordon, mentions only one conflagration, which he places in $1765 . .^{4}$ Nelson, after assessing and then discounting the testimony of previous writers, concluded that the engine-house

${ }^{1}$ A square-rigged vessel, now rare, differing only slightly from a brig.

${ }^{2}$ For the best account see William Nelson, "Josiah Hornblower and the First SteamEngine in America," Proceedings of the New Jersey Historical Society, and Ser., VII (1883), pp. 177-230.

${ }^{3}$ [Benjamin H. Latrobe], American Copper-Mines, n.p., n.d. The Rutgers University Library possesses this rare, eight-page pamphlet, which is addressed "To the Chairman of the Committee of Commerce and Manufactures, to whom has been referred the petition of N[icholas]. I[ames]. Roosevelt and his Associates, praying for an act of incorporation of a Mine and Metal Company." It was probably written in $180 \mathrm{r}$.

${ }^{4} A$ Gazetteer of the State of New Jersey (Trenton, I834), p. I1. 
had been destroyed in 1773 , for it was in that year that the financial accounts of the mine came to an abrupt end.

On the basis of evidence that was not known to Nelson and his predecessors, it is at last possible to fix the dates of the fires with certainty. The New York Mercury for March 22, I 762, reported that one week earlier the building which housed the engine "took Fire and was burnt to the Ground, and the Works belonging to the Engine, which it is said cost near Ten Thousand Pounds, were destroyed." It was conjectured that the blaze was caused by a careless workman who left a candle burning on the first floor after he had retired to his sleeping quarters upstairs. ${ }^{5} \mathrm{~A}$ brief account of a second destructive fire was printed in The Pennsylvania Chronicle of July $25, \mathrm{I} 768$.

New York, July 21. We hear from Newark, that on Monday

Night last, [July I7] Schuyler's Copper Works, at Second

River, which were burnt about 7 Years ago, were again de-

stroyed by Fire, supposed to be by Design, as it was not known

that any Fire had been lately used there. ${ }^{b}$

It is doubtful whether a third fire occurred in I773. There is no mention of such an event in the contemporary press, nor is the reasoning adduced by Nelson in support of his conclusion convincing. In all probability the cessation of mining activities in that year was due either to financial or technological difficulties.

A letter now in the possession of the Rutgers University Library not only gives an excellent, first-hand description of the fire of I 768 but also affords an insight into the tangled affairs of the ill-fated copper mine. It reveals that the suspension of mining activities was not caused by the accidental destruction of the engine house but was rather the result of the typical problems which beset mining entrepreneurs in a country where capital, mechanical skills, and equipment were extremely scarce. The writer, Josiah Hornblower, leased the mine from the Schuylers in $176 \mathrm{I}$ in partnership with one John Stearndall under an arrangement whereby one-seventh of the ore produced was to be paid as rent. Four years later the two partners assigned half of their interest to a group of Philadelphia speculators. After the ruinous fire the works were apparently idle until I770,

${ }^{5}$ Neaw Jersey Archives, Ist Ser., Xxiv, p. I 9.

${ }^{6}$ Ibid., XXVI, p. 220. 
when a New York syndicate became interested in the venture. In I 773 operations were again halted, and no attempt was made to resume them until after the Revolution. During the first half of the nineteenth century several companies were organized at various times to exploit the still-rich veins of ore, but all of them were shortlived and unprofitable. As for the ancient engine, it was broken up around 1800 , and half of the cylinder eventually came to rest in the Smithsonian Institution. ${ }^{7}$ Hornblower's letter, in which he acquaints one of his partners with the financial difficulties that led to the closing of the mine, is printed below.

Sir

Schuyler's Mine 23 July I 768

When I reflect on the conversation I had with you last July at Second River respecting the affairs of Schuyler's Mine, \& the repeated promises you then made, to send by the first oppertunity the Ballance due to me for money advanced to the Works; \& how greatly you have failed in the performance thereof; I am utterly unable to form one probable reason to account for such a conduct: especially when I consider, that you must have known the Mine, \& consequently the Intrist of all concern'd therein, was likely to suffer by it. If you had conceived any ill opinion of the Works, or of my manner of conducting them, or both, you would no doubt have freely express'd it; but no such thing, not the least hint of this kind was ever given me; on the contrary, as far as I could perceive, you appear'd to be well satisfied. After waiting some months, \& being assured that several oppertunities had been neglected by which you could have supply'd me with cash, I concluded, that no such thing was ever meant or intended. Therefore, I stop'd all those parts of the Mine as were not then absolutely necessary for the present working the Vein, with design to pay myself out of the profits of the Ore, which design I should have easily effected if the Vein had remain'd as large as usual, but It unfortunately happen'd shortly after you went from hence, to diminish, to such a degree, that the most experienced Miner could hardly per-

${ }^{7}$ L. F. Loree, "First Steam ("Fire") Engine in America." An address delivered before the Newcomen Society in New York City, April 24, 1929. 
ceive any Vein at all. In this scituation It continued 'till about the 2oth October, \& then enlarg'd a little but afterwards remain'd small, 'till the latter end of December, when I was oblig'd to stop the Engine for want of Fuel. yet notwithstanding these discouragements, I had still expectations of the Veins enlargement, \& of accomplishing my design; Therefore I procured in the best manner I could another stock of Fuel, put down the old pumps, \& made all necessary repairs, and in the beginning of Aprill set the Works on again, The Stoops \& the Sump, ${ }^{8}$ I carried on together, \& sunk down the latter deep enough as I imagin'd to allow me the advantage of a Sumer's work on the Vein, but It soon took an uncommon dip, \& got below our Stoops, but as It appear'd at the same time to be increasing very much in Its dimensions, I endeavour'd to follow It with hand pumps, but found them insufficient to draw the water. This Sir oblig'd me, either to sink down the Sump, \& drive up an under level, or stop the Mine; as the former would have been going to a great \& certain expence, for an uncertain profit, $\&$ being deserted as it were by my partners, or at least deprived of their immediate advice, I perferred the latter: Accordingly on monday last after the Tools were brought up, the Engine pumps secur'd \&c, I discharged all the hands; when to compleat all our other misfortunes, about eight o'Clock on the evining of the same day, the Engine House was seen to be on fire, which burned with such impetuousity, that the utmost efforts of a great number of people, could not prevent It from being reduced to a heap of ruins in a few minutes. how it happened cannot well be accounted for, a person went into It about two hours before with design to light his pipe, but says, he could [not] find any fire to light it with This is now the deplorable situation of the Mine, \& you know Sir, that our Lease becomes void \& forfieted (if we neglect working It) in six months, \& in eighteen months if we do not rebuild the Fire engine. The Vein as I observ'd above appeared to be very good \& still encreasing, which may enable us, if we do not chuse to work It ourselves, to dispose of

${ }^{8} \mathrm{~A}$ stoop-or stope-is an excavation for extracting ore in successive steps or ledges. A sump is a depression sunk below the lowest level in a shaft to receive water and form a pool from which it may be pumped. 
the Lease before It is forfieted for some consideration. All the Ore I have been able to raise since last July, amounts to about 44 Tons including IO or I 2 Tons now by me, at the expence of about $E_{3900}$ therefore the Mine has sunk since that time about $£_{700}$, and as will appear, by the whole state of the Accounts, you now stand indebted to me for yourself \& constituents, about $\mathfrak{E}_{75}$. These matters Sir I hope you will lay before the other gentlemen concern'd without delay, and advise me by the first oppertunity how, or in what manner I am to act, I also beg that you will not fail sending me at the same time the above Ballance, or at least part of it, as no person can be in greater present want of It than

Sir Your most obedient Serv ${ }^{\mathrm{t}}$ :

[signed] Josiah Hornblower 